\title{
Gandhian Concept of Freedom and Non-Violence and Its Viability in Today's Society
}

\author{
Banashree Bhardwaj ${ }^{1}$, Ionee Basumatary ${ }^{2}$ \\ ${ }^{I}$ Deptt. Of Philosophy, Kokrajhar Govt.College, Kokrajhar, Assam, India \\ ${ }^{2}$ Deptt. Of Political Science, Kokrajhar Govt.College, Kokrajhar, Assam, India
}

\begin{abstract}
Mahatma Gandhi was a difficult person, quite adamant and stubborn with his principle of nonviolence but eventually it was non-violent resistant that won freedom for us, the Indians with all dignity, respect and awe. Gandhian concept of freedom is necessary more than anything else in the present day conflict torn world; a world where man is pitted against man, nation against nation and religion against religion. If we strive for freedom, then Gandhian principles are the pre-requisite which will lead us to that freedom. Freedom is the sum total of self-respect, self-restraint and maturity as preached by Gandhi and which can alone be attained through non-violence. History bears evidence where freedom was won by waging war at the expense of lives; however history has also shown freedom or 'swaraj' can be achieved through Gandhian non-violence. This non-violent way of life may bring an end to internal struggle or disputes in several parts of the world which is being frequently witnessed today. With this aim in view, our present paper is an attempt to analyse Gandhian concept of freedom and non-violence to indicate its potential contribution to the present day society.
\end{abstract}

Keywords: conflict, freedom, internal struggle, non-violence, values.

\section{Introduction}

Being a great statesman, thinker, humanist and an apostle of peace of the $20^{\text {th }}$ century, Gandhian philosophy has always been a topic of discussion especially in today's world where his ideas appear redundant amidst the pragmatism and materialism which prevails to discard his thought. His concept of freedom is not only freedom from coercion and domination; it is also self regulation through self-restraint. Similarly, nonviolence can be employed in all spheres of life. Through his revolutionary concept of non-violence, Gandhi led the Indians and obtained freedom. Although as a patriot he will be ranked with Washington, Mazzini and Sun Yat-Sen, his achievements were not confined to bringing independence to four hundred millions. By his insistence on the application of purity to politics he gave shape to the aspirations of the noble humanity of all ages.

\section{Concept Of Freedom}

Gandhiji never tolerated the sub-ordination of one nation or individual to the other. He wrote in 'Harijon', in 1942, "No society can possibly be built on a denial of individual freedom. It is contrary to the very nature of man." Denial of liberty is virtual death. A real freedom is one which can be attained with self-efforts without any aid from any corner. Freedom is always essential because without that a nation or an individual cannot fully develop himself.

In Gandhi's philosophy we can also find a tremendous urgency for political freedom. He emphatically pleaded for freedom in the sense of national independence. For him, India was supreme and above everything else.

Gandhi accepted the truth of famous Mantra given by Bal Gangadhar Tilak that 'swaraj' (freedom) is the birthrights of the Indians. He said, "For me every ruler is alien that defies public opinion." The 'swaraj' of Gandhi's conception was to champion the interest of the down-trodden and starving millions. 'swaraj', for him was part of truth which is God. Real freedom or 'purna swaraj' in India will come when all shall have equal opportunities. According to him, a solitary act of heroism could not bring freedom to India, but collective and constructive efforts of citizen alone could bring the desired fruit. Gandhi also advocated freedom of speech and pen and this was the foundation of 'swaraj'.

Gandhi also pleaded for moral freedom. For him, moral freedom lay not in the egoistic assertion of the individual, but in the identification with the spiritual being.

Gandhi never accepted the theory of freedom as arbitrariness of licence. Freedom results in self denial for the sake of society. Licence means desire to enjoy exclusive privileges even by resort to violence. But to Gandhi, freedom was a whole. Moral freedom as emancipation from the slavery of passions, national freedom from the bondage of alien rulers and exploiters and spiritual freedom as emancipation and realization of truth were all phases of freedom. 
In western psychology and philosophy there is an unhealthy separation between the different forms of freedom i.e. the metaphysical freedom of human against cosmic necessity, the psychological theories of freedom of will and action and the discussions about the reconciliation of individual political freedom and social authority. But Gandhi's attitude was integral. To him, freedom was a process of growth in quest of articulated system of coherent moral purposes and actions. Here, a resemblance can be drawn between Gandhi and Plato. Both have a spiritual approach to history. Freedom, according to both can be attained through the inner purification. Ethics is not a matter of outward conformity but should be founded upon knowledge. The basic difference between them was that Gandhi is more of a humanitarian than the aristocratic Plato.

\section{Gandhi On Non-Violence}

Another notable feature of Gandhi's thought is advocacy of non-violence or 'ahimsa'. It may be observed that the concept of 'ahimsa' was not an original contribution of Gandhi and had been practiced in India since time. He was very much influenced by the ethics of Jaina philosophy which incorporated 'non-violence' in a wider way. The word 'non-violence' is commonly understood as non-injury to living beings or dynamic harmlessness. But Gandhi presented non-violence in a new form and shape before the world. Gandhi said, "Non-violence is the first article of my faith. It also the last article of my creed." He defined non-violence as the active force of the highest order, "It is the soul-force on the power of Godhead within us." The form of his nonviolence is not escape or exile but resistance. Pure non-violence, according to Gandhi is hurt by every evil thought, by anger, by wishing ill to anybody, by hatred, by fear, by selfishness, by lying, by undue haste and by attachment. Therefore, conditions for non-violence are that one must avoid these evils conscientiously.

Gandhiji marched forward using non-violence as the best weapon to encounter immorality for morality, inhumanity for humanity and injustice for justice. Thus Gandhi's concept of non-violence was positive concept which was based on good will towards all. It even included love for evil doer and sinner but with the hate of the evil and sin.

\section{Relation Between Freedom And Non-Violence}

Gandhi wanted non-violence to be the spirit of life and to fuse it all relations-familial, social, and political, economic and educational. His objective was to create a society based on the principle of non-violence, where man's freedom would be safe and mankind would be free from repression and tyranny. He said, "Individual freedom can have the fullest play only under the regime of unadulterated 'ahimsa'."

The absence of violence brings lasting peace. Peace is visible when there is freedom, equality, justice, good governance and the protection of human rights. For Gandhi, such a democracy can succeed only through a science of non-violence.

\section{Practical Relevance}

Gandhian concept of freedom and non- violence are pre-requisite for total development including the personality of a man. In a world of increasingly beset by violence and terror, the value of spirituality as propounded by Gandhi is of paramount need today.

Today more than any other time in history peace seems remote and has become the most unattainable goal in the world. Violence assaults our planet every hand. Personal violence, domestic violence, religious violence, communal violence has climbed to unprecedented proportions. Under these circumstances, the gospel of non-violence summons us to be loving, tolerant, forgiving, selfless and compassionate. So, it is essential to stress the significance of Gandhi's message which makes an appeal to the values of human being in an age when the humanistic structure has been rudely and savagely attacked by the extraneous might of weapons of mass destruction.

\section{Conclusion}

Thus concept of freedom and non-violence are the two universal phenomenon of which ultimate goal is the harmonious co-existence of all life forms in the universe. Non-violence had always been the founding principle of Gandhian spirituality and bedrock of his political philosophy. Since the end of the World War-II the world has shown many examples of the success of 'ahimsa' against tyranny and injustice. The Negroes of the United States is a glaring example. Gandhi's ideal of non-violence inspired many leaders like Nelson Mandela, Martin Luther King junior, Aung San Suu kyi and our own Irom Sharmila of North-East India. Recognizing the importance of non-violence in the life of Global community, the UN general assembly resolved to observe October 2, the birthday of Gandhi, as the international day of non-violence desiring to secure a culture of peace, tolerance, understanding and non-violence among the countries. This resolution is the reflection of recognition of the Gandhian ideals and methods in today's world which is confronted with ever growing terrorism and violence. 


\section{REFERENCES}

[1] Arora, N.D\& Awasthy, S.S (2005): Political Theory, Har-Anand publications pvt. Limited, New Delhi.

[2] Chakraborty,B \& Pandey, R.K(2009): Modern Indian political Thought, SAGE Publications India Pvt. Limited, New Delhi.

[3] Gandhi, M. K.(last reprint 2007): The Story of my experiments with truth, navajivan publishing house, Ahmedabad.

[4] Johari, J.C(1995): Principles of Modern Political Science, sterling Publishers Private limited, New Delhi.

[5] Mahajan V.D (2003): 'political theory', S. Chand \& company Ltd, New Delhi.

[6] Kachchapilly J(2005): 'Gandhi and Truth', Akansha Publishing House, New Delhi.

[7] Sarma Nilima (1999): 'Twentieth century of Indian philosophy, Bharatiya Vidya prakasana, Delhi.

[8] Varma, V.P (2009): Modern Indian Political Thought, Lakshmi Narayan Agarwal Educational publishers, Agra.

[9] The Assam Tribune dated $2^{\text {nd }}$ October, 2006.

[10] The Assam Tribune dated $2^{\text {nd }}$ October, 2013. 